\title{
Gencay ve Doğanın Sıfır Noktası
}

\section{Özet}

20. yüzyıl söz konusu olduğunda iki önemli savaşın sosyal, kültürel, siyasal ve ekonomik bağlamda kırılma noktası olduğu gerçeği ile karşılașırız. İkinci Dünya Savașı ve sonrasındaki süreç, farkı coğrafyalardaki sanatçıların eğilimleri ve öncü akımlara farklı bir sanat dünyası ölçeğinden ekledikleri üsluplar, bireysel ve toplu sergiler, savaşın yarattığı yıkıma ve her türlü olumsuzluğa bir cevap, ayn zamanda eylemdir. 1957'de Düsseldorf'ta doğan ZERO akımının beslendiği nokta savaşın yıkımıyla durağanlaşan dünyadaki sanatın varlığını yeniden duyumsatmaktır. Iş̧te o yıllarda İtalya'da bulunan Gencay Kasapçı Zero grubunun sergilerine katılan Türkiye'den tek sanatçı olarak tarihe geçti. Amo bu tarihe geçișin keșfedilmesi için aradan yıllar geçmesi gerekti. "ZERO: Geleceğe Geri Sayım" bu tarihe geçişin keşfedilmesi için aradan yıllar geçmesi gerekti. "ZERO: Geleceğe Geri Sayım"
sergisi, 2 Eylül 2015 - 10 Ocak 2016 tarihleri arasında İstanbul - Sabancı Üniversitesi Sakıp Sabancı Müzesi'nde gerçekleştiğinde, Gencay Kasapçı'nın adı Türkiye'deki ilk ve tek Zero sanatçıs olarak anılmaya başlandı. Makalenin ana fikri, Gencay Kasapçı'nın sanat yaşamındaki bu başlangıç noktasının araştırma, belge ve kaynaklar doğrultusunda yeniden vurgulanmasını amaçlamaktadır.

Anahtar Kelimeler: Gencay, Gencay Kasapçı, Zero, Sonsuzluk, Optik Sanat, Yanılsama

\section{GENCAY AND THE ZERO POINT OF NATURE}

\section{Abstract}

When the 20th century is at stake, we encounter the fact that two important wars were breaking points in social, cultural, and economic contexts The process during and after the World War II, the orientations of the artists in various geographies and the styles they added on the pioneering currents from the perspective of the world of art, solo and group exhibitions are a response to every kind of negativity and at the same time an action. The point from which the ZERO movement that arose in Düsseldorf in $1957 \mathrm{fed}$ on was making people re-feel the presence of art in the world which was becoming stationary with the destruction of war. Gencay Kasapçı who was in Italy in those very years made history as the only artist from Turkey who participated in the exhibitions of the Zero movement. However, many years had to pass for this state of making history to be discovered. When the "ZERO: Geleceğe Geri Sayım" ("ZERO: Countdown to the Future") exhibition was held on 2 September 2015- 10 January 2016 in Sabancı University Sakıp Sabancı Museum Gencay Kasapçı's name started to be mentioned as the first and the only Zero artist in Turkey. The subject matter of this article aims to research this starting point in Gencay Kasapci's art life and re-emphasize it in accordance with documents and resources.

Keywords: Gencay, Gencay Kasapçı, Zero, Infinity, Optical Art, Illusion 
Gencay Kasapçı'nın 1962 yılında Venedik'teki II Cavalino Galerisi'nde açtığı kişisel sergisi ile ilgili Guiseppe Mazzariol'un (1962) kaleme aldığı katalog metninde, önemli saptamalar yer aldı:

Hiç kuşkusuz bu genç Türk ressamının figüratif uzak görüşlülüğünün kökenlerinde Bizans sanatından gelen esinleri yakalayabiliriz. Bu tabloların karşısında akla gelen, dillerden dökülen ilk yorum kesinlikle bu. Öylesine anında, öylesine az düşünerek söyleniyor ki, adeta bir tür keyif veriyor. Oysa bu çıkarım pek de o kadar belirgin değil. Klasik anlamda varsayımlar ya da göndermelerin bilgiyle yoğrularak özenle incelenmesinin ardından ortaya çıkıyor. Gencay'ın vizyonu huzurla bütünleşiyor; Bizans metropol uygarlı̆̆ından ince bir çizgiyle ayrılmış, ufacık bir teması kalmış, ama bu kadarı bile bu yoruma neden olmaya yetiyor. Belki de bu bir bilince varma durumudur. Soylu ve pırıltıı bir anı, törensel temaların, törenin asıını merak ettirmeden yansıması. Hem fazla, hem de farklı olmadan Gencay çağdaş bir kadın olarak bizim dünyamızda yaşıyor, üretiyor ve üstelik hem pişmanlıklara, hem de özlemlere başvurmuyor. Günümüz dünyasının ezmeye çalışıı̆ı gelenekse değerleri korumayı başarmış bir kadın. Yaşama dengeli, içten, huzurla ve iyimserlikle yaklaşıyor. Resimlerinde kullandığı dil alabildiğine sade. Tekrarlanan şekiller teorisi, bu teorinin dozunun bilgece ayarlanmış olması ve krom hesabı, bu resimlerin her birine gerekçesiz bir parlaklık katmakta. Kullanılan malzemenin sıradanlığı, uygulamadaki sadelik ve her tür artizanal tekniği, adeta yok sayması, tablolarının eşsiz olmasını sağlamış, sanatsal fikir ile uygulama arasındaki uyumu vurgulamış, proje ile gerçeği bütünleştirmiştir. En doğrusu bu eserlerin tanımını eserleri okuyacak kişilere bırakalım: Her bir formun, kesimin, sönen ve birdenbire yanan renklerin arasında gezinsinler. Herkesin mutluluk duyacağını, zamanının ve kendisinin bilincine varacağını, hem gizemli hem de güncel bir uygarlığa ressamın müthiş bir ayna tuttuğunu fark edeceğini düşünüyorum. ${ }^{2}$

Tüm bu sözlerle makalenin, giriş bölümündeki başlangıcı yapmanın bir amacı bulunmaktadır. Çünkü 1962'den (Görsel 1) bu yana yani 2017 yılına kadar sanatçının resimlerinin okunmasında "Optik Sanat"ın varlığının sorgulandığı bir sürece tanıklık ediyoruz. Plastik sanatlarda resim optik bir değer taşır ve ışık, renk ve görsel algı problemleri önemlidir (Tuğal, 2012: 57). Tarihteki örnekler, bu saptamayı geçerli kılar; geçen yüzyılın Victor Vasarely (1906-1997), Jesus Raphael Soto (1923-2005) ve Lucio Fontana (1899-1968) gibi gerçeği alımlayıcıya çok boyutlu olarak yansıtan

Gencay Kasapç'yı 29 Kasım 2017 tarihinde Mersin'de kaybettik. Uzun yillar özellikle Ankara sanat ortamının oluşmasında hem sanatçı hem de sanat galerisi yöneticiliği kimlïgiyle önemli bir tutan sanatçının Zero grubuyla adının anılması ancak ve ancak 2015 yllinda olmuştur. Böylesi bir gecikmenin sebebinden çok bundan sonra. bu kadin sanaţ̦ının Türkiye Plastik sanatlar alanındaki haklı yerine kavușması iç̧in oldukça fazla görevimiz düștüğünü bu makale ile akademik bağlamda belgelemekteyiz.

Bkz.http://www.gencaykasapci.com/pPages/pArtist.aspx?palD = I I0\&section=550\&lang $=T R \& b h c p=1$ \&periodID $=$ \&page No $=13 \&$ exhID $=0$ sanatçıların öncülüğünde yeni bir akımın kapılarını açtı.

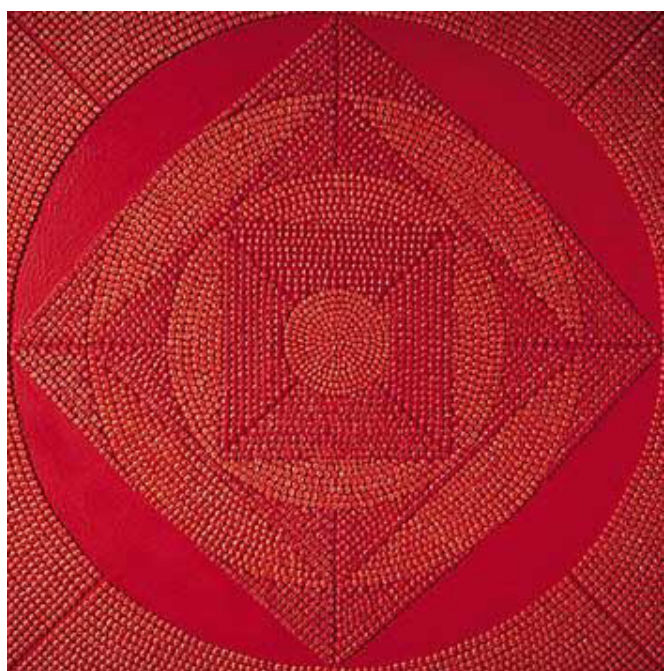

Görsel I. Gencay Kasapçı, Kırmızı Oluşum, 1962, Roma, Ahşap Üzerine Karışık Teknik, $80 \times 80 \mathrm{~cm}$.

1964 yılında Gencay Kasapçı (1933-2017) İtalya'daki serüveni sırasında Lucio Fontana ile karşılaştı (Görsel 2) ve resimlerine ait olduğu kültürün değerlerini de ekleyerek, doğa merkezli, ışığı sorguladığı optik yanılsamaya dayalı sonsuzluğa açılan ve "sonsuz olanı sonlu olanda" ortaya koyduğu kavramın temelinde, kendi üslubunu oluşturdu.

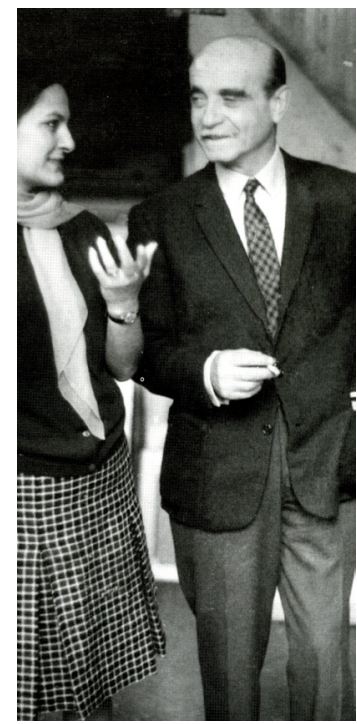

Görsel 2. Gencay Kasapçı Ve Lucio Fontana, Roma’da Sergi Sırasında (1964). 
2015 yılına kadar sanatçı hakkında yazılan tüm yazıların incelenmesi ${ }^{3}$, bu makaledeki temel amacın ya da sorunun sanatçının eserlerini bir sınıflandırma içinde belirlemekten çok daha farklı bir yönde gelişmesini ve yeni saptamaların belgeler ışığında ele alınmasını sağlar. Gencay Kasapçı'nın Türkiye Resmi'ndeki yerini, hem de bir kadın sanatçı kimliğiyle belirlerken, Batı'nın 1960'larda onun için kullandığı çıkarımlar üzerinden kendi ülkesindeki yazılanların genişlememesidir. Çünkü açtığı sergilerin kataloglarındaki metinler incelendiğinde, optik yanılsamaya dayalı resimlerinin doğa sevgisi temelindeki lirik yönü, mercek altına alınmıştır. Jale Erzen haklı olarak 16 Kasım - 05 Aralık 1989 tarihleri arasında Ankara Emlak Bankası Sanat Galerisi'nde sanatçının açmış olduğu kişisel sergisi üzerine kaleme aldığı katalog yazısında, 1970'lerde Batı'da Lars Nilsson, Agnes Martin, Larry Poons ve Walker Tomlin gibi sanatçıarın sistematik resmin nitelikli örneklerini verdiğini vurguladı.

Bu niteliğin bizdeki adının ise Gencay Kasapçı olduğunu ve 1966 yılında Türkiye'ye dönüşünden önce sanatçının soyut minimalist akımın içinde, Zero grubu ile avangarde galerilerde resimlerinin sergilendiğini yazdı (Erzen, 1989: 4). Yani durum şiirsel, lirik ve de optik süreçten geçmekten daha fazlasına işaret etmektedir.

Avangarde tavrın onaltı yıllık serüveninde, sanatçının resimlerinde malzeme ne olursa olsun, hep doğanın kendisi vardı (Görsel 3). Ama öncesinde optik sanat sürecinin nasıl oluştuğuna bakmak yerinde olacaktır. Çünkü Gencay Kasapçı'nın hareket yanılsamasını ön plana çıkaran resimleri, doğaya dönüş yaptığı süreçle (1980-1990) birlikte ele alınmalıdır. Işık ve optik mekân olarak seçtiği alan doğanın kendisi oldu. Soyutlama anlayışına dayalı renk ve lekelerin içinde kaybolan her nokta bir bakıma izleyenin gözündeki görsel mekanizmayı harekete geçirerek, uyarmayı amaçladı. 2000 'li yılların sonunda geldiği noktadan sanatçıya baktığımızda ifade yollarını farklı malzemeler üzerinde çok aza indirgediğini, çoğu kez yalın biçimler üzerinden çalıştı̆̆ını, aslında sanata başladığı yıllarla eş ve fakat güncel konularla iç içe bir duruş sergilediğini söyleyebiliriz (Görsel 4, 5).

Optik Sanat, ikinci Dünya Savaşı sonrasında geçerli olan "post painterly" anlayıșa karsıt olarak Avrupa'da ortaya çıkmıs bir akımdır (Germaner, 1997: 27). 1965 yılında, New York Modern Sanat Müzesi'nde açlan “The Responsive Eye" adlı sergi düzenlenmesi ve Time dergisinde yayımlanan bir makalede adının kullanııısı akımın tanımlanmasını sağlamışı (Germaner, 1997: 27). Gencay Kasapçı, 1959 yılında Italya'dan kazandığı bursla Floransa Akademisi'nde Collaccki Atölyesi'de eğitimine başladı.

${ }^{3}$ Bkz. http://www.gencaykasapci.com/pPages/pArtist.aspx?palD= 1 10\&section = 550\&lang =TR\&bh$c p=I$ \&period $I D=\& p a g e N o=0 \&$ exh $I D=0$

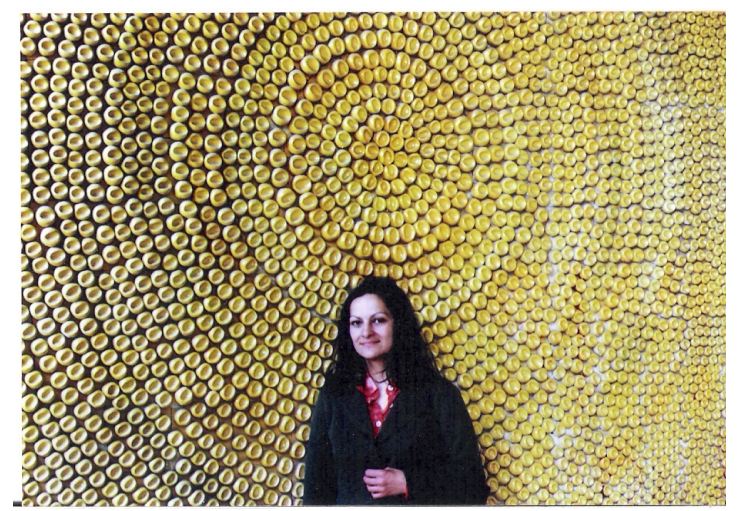

Görsel 3. Gencay ve Seramik Pano, 1968, Seramik 18 m2, ODTÜ Mimarlık Fakültesi Girişi

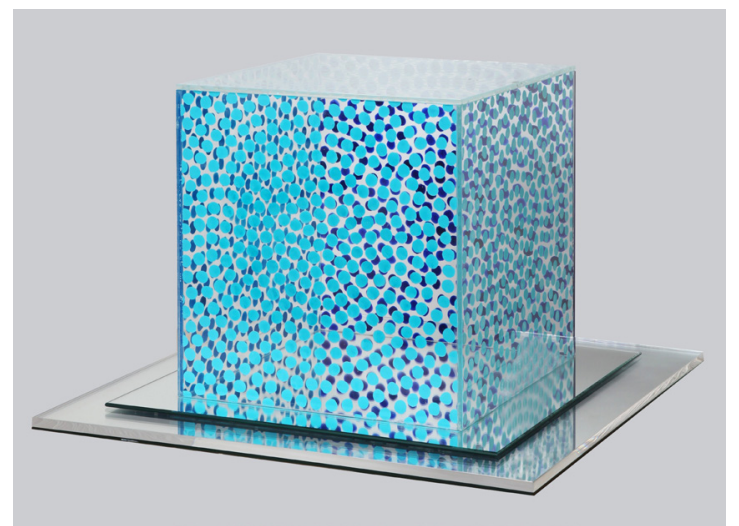

Görsel 4. İsimsiz, 20II, Pleksi, Cam, Karışık Teknik, 30×30×30 cm.

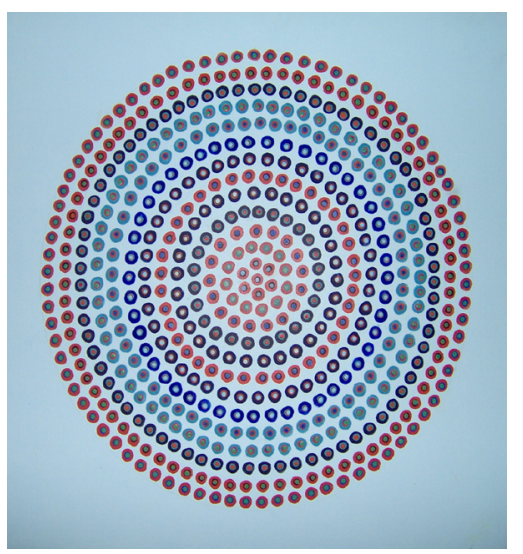

Görsel 5. Gencay Kasapçı, İsimsiz, 2012, Karışık Teknik, 100x100cm. 
Maliye Bakanlığı'ndan sanatçının aldığı özel izinle, bir bavul dolusu nazar boncuğu da kendini İtalya'da buldu. Sanatçının bu dönemi "Optik Dönem" olarak adlandırılsa da yaptığı resimlerin farklı olduğunu belirtti. Gözüyoran, şaşırtan, acıtan yansımaların yerine resimleri, tek renk etkisi veren yumuşak titreşimlerle hareketlendi (Görsel 6). Optik süreç 1966 yılında Türkiye'ye dönüşüyle birlikte yüzeylerindeki üslubun yönünü belirledi. 2000-2017 yılları arasındaki tüm deneysel arayışlarında sanatçının bu döneminin etkin rol oynadığını söyleyebiliriz. Boncuklar, renkli kâğıt parçaları ve üç boyutlu düzlemde cam ile birleşen farklı malzemelerdeki optik düzenler, sanatçının ömürlük yorumlarının dengeli adımlarıydı. Özellikle söz konusu zaman sürecinde, nazar boncuklarına dönüş yaptığını ve ağaçlardan yükselen her renkte yine bu boncukların üzerinde yoğunlaşan renk kıpırtılarııın, özlemli bir yönde geliştiğini 2010, 2011 ve 2012 yıllarına ait resimleri, yüzey düzenlemeleri ve üç boyutlu işleri göstermektedir (Görsel 7).
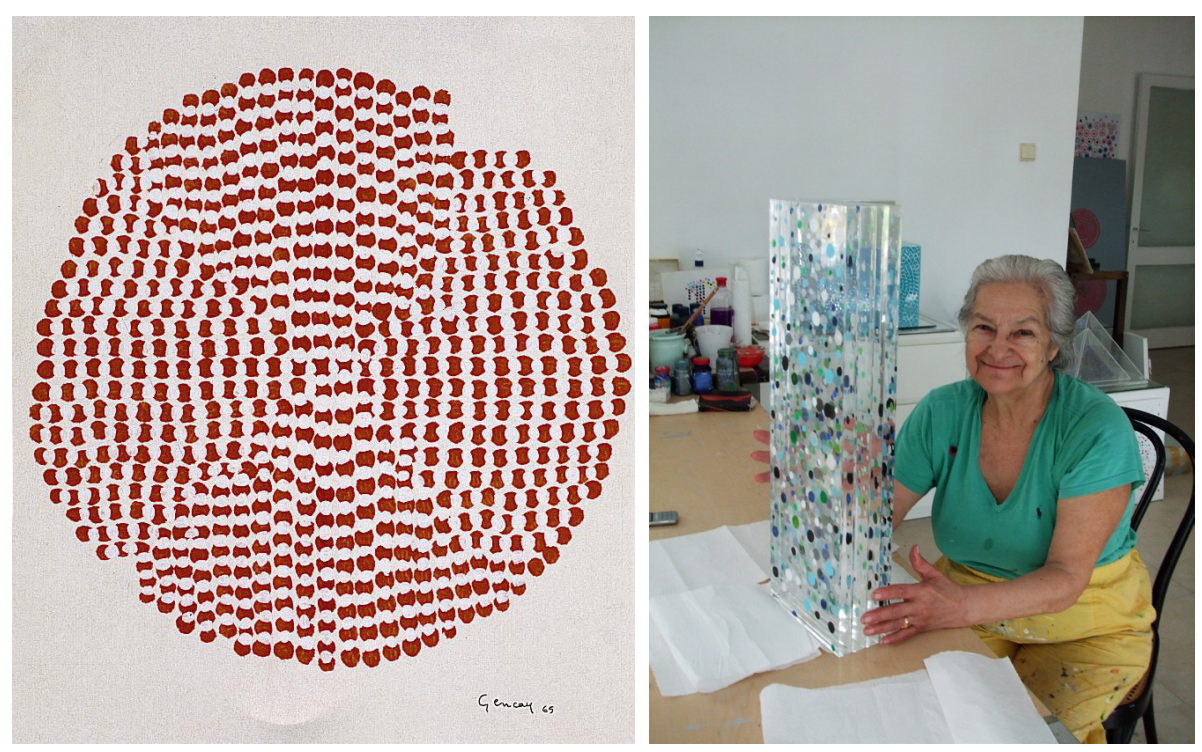

Görsel 6. Gencay Kasapçı, İsimsiz, 1967, Kă̆ı̈t Üzerine Akrilik, $40 \times 30 \mathrm{~cm}$. Görsel 7. Gencay Kasapçı Mersin'deki Atölyesi'nde

Gencay Kasapçı'nın sanat yașamında Türkiye Sanat Tarihi'nde çok az bilenen diğer bir önemli husus ise İtalya'da bulunduğu süreç içerisinde Zero grubunun sergilerinde yer alması konusudur. Optik düzenlemeleri, Ağaçları, doğa izlenimine dayalı kuşların ve yaprakların soyutlamaya dayalı renk ve leke titreşimlerine dayalı tüm işlerinin odağında Zero grubu

${ }^{4}$ Gencay Kasapçı ile 2012 yılında yapılan kitap çalışması sırasındaki konuşma sürecindeki notlardan aktarılmıstır. ile katıldığı sergi gözden kaçmıştır. 1990'lı yıllar sanatçının Ağaçları ile anıldığı sergilerin birbiri ardına açıldığı dönemlerdi. "Damıtılmış Doğa'nın Imgeleri" tanımını Onder Şenyapılı, Iş Bankası Sanat Galerisi'nde 9 Kasım - 1 Aralık 1993 tarihleri arasında gerçekleşen sergi üzerine kullandı. Sergi için basılan kataloğa Şenyapııı'nın şu satırları yansıdı: "O ağaçlar ki özgürlüğü simgeler" (Şenyapıll, 1993: 3). Gencay Kasapçı, yıllar sonra verdiği röportajında 1959-1966 yılları arasındaki Italya yıllarına özlemini dile getirirken yurda dönüşünün pişmanlığını anlattı.

"ZERO: Geleceğe Geri Sayım" sergisi, 2 Eylül 2015 - 10 Ocak 2016 tarihleri arasında İstanbul-Sabancı Üniversitesi Sakıp Sabancı Müzesi'nde gerçekleştiğinde, Gencay Kasapçı'nın adı “Türkiye'deki ilk ve tek Zero sanatçıı" olarak anılmaya başlandı (Erciyes, 2015: 18). 60'lı yılların Avrupa'daki etkili sanat akımı Zero grubunun sergilerinde sanatçının yer alması yaşamındaki dönem noktalarından biri olarak bizzat kendisi tarafından anılmaktaydı ${ }^{5}$. Zero sergileri sanatçının hem italya hem de daha sonraki yıllarda Türkiye'deki sanat yaşamı için önem taşıdı.

Sabancı Müzesi'nde gerçekleştirilen Zero: Geleceğe Geri Sayım sergi kitapçı̆ı̆ında (2015) yer alan șu cümle Gencay Kasapçı'nın ișlerindek Batı kaynaklı dilinin özetidir: "Geleceğe dair sarsılmaz bir umut ile yola çıkan Zero sanatçılarının doğa ve teknolojiyi farklı teknik ve malzemelerle ele aldığı geniş bir seçki sunulmaktadır" (s. 6). Farklı teknik ve malzeme kullanımına dair sanatçı yaşamı boyunca deneysel işlerden yana bir tavır sergiledi. 1959 yılında italya'da başlayan hikâyesi onu Zero Grubu'nun sergileriyle tanıştırdı. Optik resimler üzerinde çalıştığı yıllarda (1959-1966) "Gencay" " imzasıyla ZERO grubunun sergilerine katıldı (Görsel 8).

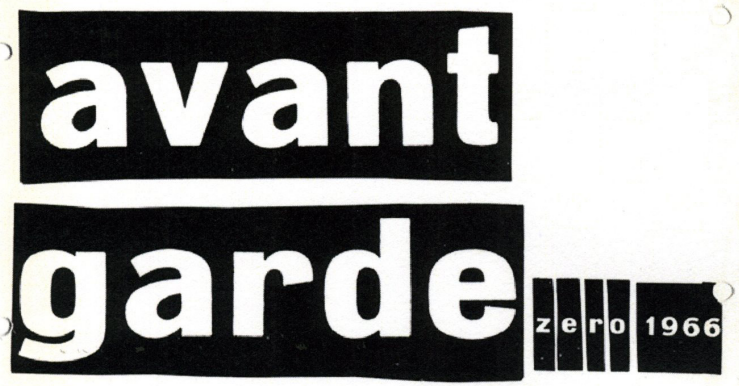

Görsel 8. Avangarde Zero Sergi Davetiyesi, 1966, Roma, Galleria II Segno

${ }^{5}$ Gencay Kasap̧̧ı ile 2012 yllında gerçekleştirilen notlardan aktarılmıştır.

"Gencay Kasapçı, sanat literatüründe "Kasapș" soyadını kullanmadı ve eserlerini her zaman "Gencay" olarak imzaladı. Açtı̆̆ı gerek kişisel gerekse grup sergilerinde tüm yazılı metinlere ve belgelere adı "Gencay" olarak geçti. 
1 Haziran 1966 tarihinde Roma'da Galleria II Segno'da açılan "AvantGarde Zero" sergisinde Lucio Fontana, Yves Klein, Heinz Mack, Otto Piene, Günther Uecker gibi sanatçılarla birlikte Gencay Kasapçı'nın da adı yer aldı. Fakat bir tashih neticesinde ismi "Gencay" yerine davetiyede "Gengay" olarak basıldı (Görsel 9). Bu o yıllarda 33 yaşındaki Gencay'ın bir Türk sanatçı olarak Italya'daki en verimli ve avangarde kimliğinin öne çıkan başarısı olarak tarihe geçti. Her sanatçının farklı malzeme ve üslubunun verdiği hazzı Gencay Kasapçı, kendi deneyimlemeleriyle buluşturdu, Türkiye'ye Batı'nın yeni olan eğilimin verileriyle döndü. 1976 yılına kadar açtığı sergilerde izlenen işlerinde, kafasındaki düşüncelerin netleștiği ve optiğin sınırsız boşluğunda doğanın renkleriyle buluşturan bir yön izledi.

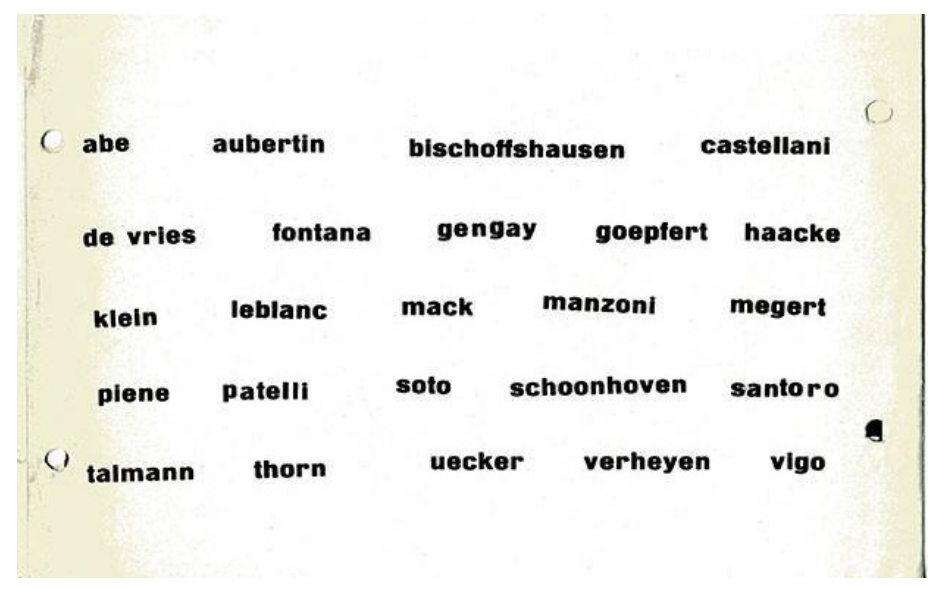

Görsel 9. Avangarde Zero Sergi Davetiyesi, Gencay'in İsminin Olduğu Sayfa, 1966 , Roma, Galleria II Segno

Gencay Kasapçı, sanat yaşamı süresince doğanın ritmini kendi düşleri üzerinden ve deneysel açılımlara cesaretle yaklaşıp derinleştirdi, kurguladığı süreçleri sanatının diline taşıdı (Görsel 10). Düşsel doğa gezintileri içerisinde ağaçlardanyükselen ritimleri, renklerle buluşturdu. Şüphesiz tüm bu resimler ve cam/ayna-nazar boncuğu tasarımlar göz önüne alındığında, sanatçının 1960 'I yıllarına kısa bir dönüş yapmak gerekiyor. Çünkü onun sanatını yakından izleyenler/tanıyanlar bilirler ki; "Gencay" ismi Türkiye Resim Sanatı'nda batı merkezli "Optik Sanat" akımının ülkemizde tanınmasını ve gelişmesini sağlayan öncü ve kilit ismidir. Bu nedenle "Optik" yanılsamaya dayalı anlatım biçimini benimsediği dev boyutlu yüzeylerle, dinamizmin ve ritmin ön plana çıtı̆ğı resimlere uzanan bir zincirin halkalarını eklemeye çalışmalıyız. Buna bir de Zero halkası eklendi.

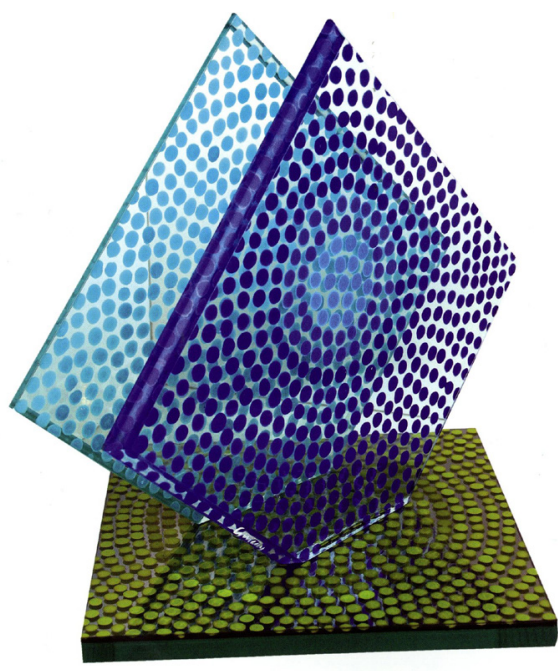

Görsel 10. Gencay Kasapçı, İsimsiz, 2006, Karışık Teknik Ayna ve Pleksi, 13 h

Gencay Kasapçı "Türkiye'de ilk ve tek Zero sanatçııı" olarak 2016 ve 2017 yıllarında önce ìstanbul ve daha sonra Roma'da "Zero/1960-2016" bașlıklı iki ayrı sergisi düzenledi. Roma'nın tarihi galerisi Galleria Russo'nun İstanbul'daki mekânı Russo Art Gallery'de 26 Ekim - 09 Kasım 2016 tarihleri arasında gerçekleșen ilk sergide sanatçının kütle-boșlukikilemlerine odaklandığı işleri, bir retrospektif anlatım düzeninde sergilendi ${ }^{8}$.

14- 21 Eylül 2017 tarihleri arasında ise küratörlüğünü Giorgio Bertozzi ve Ferdan Yusufi'nin yaptığı Gencay Kasapçı'nın ikinci "Zero/1960-2016" adlı sergisi ise Roma'da Fondazione Museo Venanzo Crocetti'de gerçekleşti . Sergi üzerine Leonardo Regano'nun kaleme aldığı makaledeki sözler önem taşımaktadır:

Roma'dakillSegno Galerisi'ndeyapılan Avant-gardeZero 1966sergisine katılmasının ardından Avrupalı avangartlar arasında sayılan ve tanınan Gencay, çok kısa sürede olgun bir sanatçı kimliğinin sahibidir. Böylelikle Fontana, Castellani, Manzoni, Klein, Soto, Piene, Mack ve Abe ile diyaloğa girecektir. Gencay Kasapçı kolektif zevkin bu kadar avangard bir dili kabul etmeye az meyilli olduğu Türkiye'ye dönüşünde yaşayacağı zorluklara rağmen, bugün sürdürmekte olduğu yeni ve özgün bir üslup ortaya koydu. Resimlerinde tekrar eden hareketler ve gestaltik sanatın tipik kombine formlarıyla, bizans mozaik dekorasyon geleneğini, Abe tarafından aktarılmış doğu felsefesinin hikmetini bir araya getirir. Gencay Kasapçı'nın sanatını oluşturan üç unsur Batı ve Doğu arasındaki mükemmel sentez, Akdeniz kökenli kültürler ve

${ }^{8}$ Bkz. http://www.artfulliving.com.tr/takvim/zero 1960-2016-i-8421

Bkz. http://www.arte.it/calendario-arte/roma/mostra-gencay-kasap\%C3\%A7-zero- 
toplumlar arasındaki çekimi yansıtan birleştirici bir ayna olarak açıklanabilir. Sert geometrik yapılarına karşın eserlerinde doğaçlamacılık ve atılganlık kendini gösterir Saf geometrik unsur olarak seçilmiş noktanın sabit tekrarına bağlı, modüler bir ressamdır, Gencay. Her tekrarında ortaya çıkan her küçük nokta kendi tekliğini kaybeder ve yeni bağımsız formlara hayat vererek daha büyük bir bütünlüğün parçası olur. Kavisler, çemberler, çizgiler tuvalde tekrar tekrar yer alırlar. Bu olgu şekillerdeki devamlıı̆̆ın ve yakıncılığın prensipleriyle tanımlanmıştır. Retina üzerine yansıyan bu yeni formlar bakan kişide sadece optik ve zihinsel değil sezgisel ve duygusal bir etki de uyandıırlar. Çünkü aslında Gencay çizdiği noktalarıyla birlikte çok ağır bir yükü sembolik olarak boşaltmaktadır ${ }^{10}$.

Sanatçının ölümünde önce, son yıllardaki tüm üretim sürecinde hep başlangıç noktasına dönerek okumaları yapmak mümkündür. Başlangıçtaki Avrupa izlerinin son dönemlerdeki heyecanlar yeniden eklendi ve Çağdaş bir düzlemde eleştirel, sorgulayan ve çevre bilinciyle birlikte renklerinden vazgeçmeden ekspresif bir bakış açısıyla avangarde yaklaşımına yeniden dönüş yaptı. Roma ve Collacki Atölyesi'nin onun sanatı için en isabetli başlangıç noktası olduğu gerçeğinin farkına varıyoruz. Tüm bunların yanında unutulmaması gereken bir diğer nokta ise, her șey bir yana, 1960'lı yıllarda, ülkesinden uzakta sanatıyla yaşamaya çalışan genç bir sanatçıydı.

Optik sanat, göze sunduğu yanılsamaya dayanan görsel şölen ile sanatçının resimlerinde odaklandı. Milano'da soyut minimalist akımın içinde avantgarde galerilerde resimleri yer aldı. Jale Erzen'in de belirttiğ gibi "Gencay Kasapçı'nın ağaçları hem organik hem de görsel bir secere ile resminin başlangııına bağııdır" (Erzen, 1989: 5) . Tüm resmin yüzeyine egemen olan homojenlikve buna bağlı ince ayrıntıların gözden kaçırı madan üzerinde önemle durulmasıyla ortaya çıkan dairesel devinim... Bu çok önemli! Çünkü bu gizemli geometri çok fazla değişmeden ancak elipsi zorlayan bir sınıra ulaşacak kadar, önce sanatçıyı içine aldı ve daha sonra ulaştı̆̆ı üçüncü gözü yani izleyiciyi büyüledi.

Gencay Kasapçı sanat yaşamı ve sanata kattıklarıyla Türkiye Plastik Sanatlar Tarihi'nin 65 yıllık bir sürecine tanıklık etti. 


\section{Kaynakça}

Erciyes, C. (2015, 13 Ağustos). "Türkiyeli ZERO Sanatçısı Gencay”. Radikal. Erişim adresi: $\quad$ http://www.radikal.com.tr/yazarlar/cem-erciyes/turkiyeli-zero-sanatcisigencay-14 I 40 /4/. Erişim tarihi: 04 Aralık 2017.

Erzen, J. (1989). Gencay'in Ağaçları, Ankara Emlak Bankası Sanat Galerisi Sergi Kataloğu, Ankara: Odak Ofset.

Germaner, S. (1996). 1960 Sonrası Sanat Akımlar - Eğilimler - Gruplar - Sanatçılar, istanbul: Kabalcı Yayınevi

Mazzario, G. (1962). Türk Ressamın Figüratif Vizyonu, Venedik II Cavalino Galerisi Sergi Kataloğu

Şenyapılı, Ö. (1993). Ağaçlar, Ankara İş Bankası Sanat Galerisi Sergi Kataloğu

Tuğal, S. (20I2). Oluşum Süreci İçinde Op Art, İstanbul: Hayalperest Yayınları.

\section{Görsel Kaynaklar}

Görsel I: Özel Koleksiyon, Dilek Şener'in Gencay Kasapçı Arşivinden

Görsel 2: Gencay Kasapçı Arşivinden

Görsel 3: Gencay Kasapçı Arşivinden

Görsel 4: Özel Koleksiyon, Gencay Kitabı’ndan, Ankara, 2012

Görsel 5: Gencay Kasapçı Aile Arşivi'nden

Görsel 6: Prof. Dr. Jale Erzen Koleksiyonu'ndan

Görsel 7: Dilek Şener Arşivi'nden

Görsel 8: Dilek Şener Arşivi'nden

Görsel 9: Dilek Şener Arşivi'nden

Görsel 10: Gencay "Beşinci Mevsim" adlı, I6- 30 Kasım 2006 tarihleri arasında The Ninth Street Gallery - New York'ta düzenlenen Kişisel Sergi Kataloğu'ndan

\section{Internet Kaynakları}

http://www.gencaykasapci.com/pPages/pArtist.

aspx?palD $=|| \mid 0 \&$ section $=550 \&$ lang $=T R \& b h c p=\mid$ \&period $I D=\& p a g e N o=0 \&$ exh $I D=0$ adresinden 05 Aralık 2017'de alınmıştır.

http://www.radikal.com.tr/yazarlar/cem-erciyes/turkiyeli-zero-sanatcisi-gencay-14 /40/4/ adresinden 04 Aralık 2017'de alınmıștır.

http://www.artfulliving.com.tr/takvim/zero/960-2016-i-842I adresinden 05 Aralık 2017 tarihinde alınmıştır.

http://www.arte.it/calendario-arte/roma/mostra-gencay-kasap\%C3\%A7zero-1960-2016-4333I adresinden 04 Aralık 2017 tarihinde alınmıştır. 